\title{
Rainwater harvesting scenarios and its prospective in Pakistan
}

Talat Farid Ahmed, Shamim UI Sibtain Shah, Muhammad Attiqullah Khan, Muhammad Azeem Afzal

National Agricultural Research Centre, Park Road, 44000 Islamabad, Pakistan, e-mail: tafa367@gmail.com

Ashfaq Ahmed Sheikh

Pakistan Engineering Council, Attaturk Avenue (East) G-5/2, P.O. Box: 1296, Islamabad Pakistan

DOI: $10.26491 / \mathrm{mhwm} / 113689$

ABSTRACT. Water is a precious commodity and water scarcity has become a serious issue in many parts of the world, especially in dense urban areas. Water resources are under increasing stress due to continuous population growth, agricultural development, urbanization, and industrialization. The gap between water demand and supply has also increased in recent years. This has resulted in increasing pressure on underground water resources as well as the depletion of groundwater aquifers at an alarming rate. Thus there is a growing need to explore viable methods and techniques to manage water availability, especially in urban areas. The objective of the current study was to determine the potential for rainwater harvesting (RWH) in the twin cities of Islamabad and Riwalpindi. We evaluated its suitability to supplement the water supply as well as contribute to groundwater recharge and flood control efforts. This could in turn help to overcome water demand, could potentially recharge depleting groundwater resources and could result in the development of a currently untapped additional water source for urban hubs.

KEYWORDS: rainwater harvesting, groundwater recharge, water supply. 


\section{INTRODUCTION}

Water scarcity is growing in many parts of the world and urban centers are most affected. Water is a major input for the existence of life on the earth. Increased population growth, agricultural expansion, urbanization, and industrialization have resulted in the depletion of available water resources in Pakistan. The gap between water demand and supply has increased rapidly. Surface water shortage impacted nearly $50 \%$ of canal supplies during the most recent drought period, which lasted from 1998-2002 (Kahlown, Ashraf 2002). Based on the current population growth rate, there is projected to be a $31 \%$ shortage of water in the year 2025, which will increase significantly through 2050 (Sheikh 2017).

The situation is putting pressure on groundwater resources resulting in a continuous draw-down of aquifers, with associated deterioration of water quality. In Islamabad where water supply is generally met from surface storage, 170 public tube wells are also pumping water for domestic and industrial uses. Long-term groundwater data in Islamabad showed an average yearly decline of $0.5 \mathrm{~m}$ in the water table (Kahlown, Majeed 2002), a trend which is still continuing (PCRWR 2018).

Thus, the depletion rate of the aquifer has become a major issue associated with the growth of human settlements in big cities. Groundwater exploitation to meet the ever-increasing domestic and industrial water requirements of the cities on a long-term basis requires assurance of a sustainable supply of good quality water (Ariyabandu 1999). Such an assurance cannot be made unless withdrawal of groundwater is replenished under a systemic artificial recharge program (Kharal 2002).

There is a double pronged strategy being followed to manage the water resources of Pakistan: (i) construction of new medium to large reservoirs, and (ii) conservation of water resources through efficient use. There is potential for the construction of medium and large dams in the country, however, this would involve huge investment, national consensus, and above all a considerable investment of time (PCRWR 2018). The other options that can be adopted are appropriate water conservation technologies and the use of non-conventional water resources such as rainwater harvesting.

RWH is defined as the process of collecting natural precipitation from prepared catchments for beneficial use. It is an ancient practice that has been used in various times, in var- ious forms, in most of the world. Allowance of rainwater runoff from the upper reaches and collection at lower reaches is called catchment-based harvesting. This is carried out by storing rainwater from rooftops in small dams or ponds. System design is based on the catchment area, conveyance system, and water storage facility.

Sazakli et al. (2017) conducted a study to assess the 12 Jordanian governorates' residential sectors for potential potable water savings utilizing RWH. They further gave suggestions and recommendations for improving the quality and quantity of RWH. Their findings showed that $5.6 \%$ of the total domestic water supply in 2005 was harvested using this technique. Samples Analysis revealed that inorganic compounds in harvested water were in line with WHO standards for drinking purposes. However, the main bacteriological parameters exceeded the drinking water limits (Sazakli et al. 2007).

In Australia, the federal government, along with several states, initiated a regulatory mechanism for water sustainability and took steps to support households buying and setting up systems for RWH that resulted in increased RWH in regional and urban areas of the country. Potential health outcomes of harvested rainwater use were also explored. Trace metals were found to be below the health limit guideline in residential areas, but not in high industrial areas. However, epidemiological evidence suggested no increased risk of gastrointestinal disease from drinking rainwater (Chubaka et al. 2018).

A research survey was carried out for harvested rainwater from buildings in Brazil which considered economic, environmental, and social implications. The authors also assessed the legislation that would be necessary in cities where this practice would be mandated. The survey concluded that there was considerable potential for potable water saving when using rainwater in buildings (Teston et al. 2018).

A research study was initiated to examine the applicability of RWH in urban Zambia. Two peri-urban water stress areas were selected. Mass curve analysis was used to design storage for the system and a rational formula was utilized for designing gutters. Tests of water samples from this system revealed that the water was drinkable (Handia et al. 2003).

Another survey was conducted in Nigeria where climate change is already impacting water supply. Harvested rainwater is the only alternative in this situation. A city with $1,156 \mathrm{~mm}$ means annual rainfall was selected. It was found that rainwater could be harvested at a rate of $74.0 \mathrm{~m}^{3}$ per annum per household. The water demand for laundry and flushing was 21.6 and $29.4 \mathrm{~m}^{3}$ per annum, respectively. It was concluded that this amount of harvested rainwater could be enough for monthly household water demand for WC flushing and laundry, except for the months of November through February. However, storage of excess rainwater during September and October would be ample to supplement the short fall in drier months. Results showed that potential water savings was highest in June and September (Aladenola, Adeboye 2010).

A research study was started in the UK to compare estimated and actual performance of RWH systems by using calculations and simulation-based approaches (Ward et al. 2012). A RWH system located in an office building was selected for longitudinal empirical performance assessment. The results revealed an average measured water saving efficiency of $87 \%$ for an 8 -month period because the system was oversized for the actual occupancy level. Thus, a smaller tank could also be utilized for this purpose. Capital payback periods of 11 and 6 years were calculated for the actual over-sized tank and the smaller optimized tank, respectively (Ward et al. 2012).

In Australia, a study was conducted to examine the sustainability of harvested rainwater in multi-story domestic buildings under different scenarios (i.e., varying roof area, floors, water price, and interest rate), in order to categorize suitable conditions where RWH systems prove to be sustainable. A water balance model was developed to calculate water savings for various scenarios. It was found that larger roof area improves water savings and financial benefits. Also, capital, such as plumbing work and maintenance costs, matter for RWH systems. It was found that the financial viability of a RWH system is enhanced by lower interest and increased water price regimes. It was concluded that it would be possible to get "pay back" from this system subject to some suggested scenarios (Rahman et al. 2010).

In the United States, an analysis was done in 23 cities from seven different climatic regions to determine the performance of domestic RWH systems. The considered systems aimed to both improve water supply to residential parcels and to reduce storm water runoff from housing drainage catchments. The results showed that performance 
is a function of climatic patterns and cistern size. Overall, the results suggested that U.S. cities could get benefits from RWH, both as a means of storm water control and as an alternative source of water (Steffen et al. 2013).

\section{WATER SITUATION \\ IN PAKISTAN}

The geographical area of Pakistan is 79,610,000 $\mathrm{km}^{2}$ lying between $30.3753^{\circ} \mathrm{N}$ and $69.3451^{\circ} \mathrm{E}$. Pakistan has an average annual precipitation of around $200 \mathrm{~mm}$, but in northern areas it exceeds $1000 \mathrm{~mm}$. About $50 \%$ of rainfall occurs during the monsoon season (July to September). Once a water surplus country having $5,600 \mathrm{~m}^{3}$ per capita in 1950 , Pakistan has turned into a water deficit country with current per capita water availability of nearly $1,000 \mathrm{~m}^{3}$ (Sheikh 2017). The water resources of Pakistan are under great stress as a result of agricultural and population growth, and associated urbanization and industrialization. Based on the current population growth rate and declining per capita water availability, the gap between water demand and supply is growing rapidly as shown in Figure 1 and further substantiated in Table 1.

\subsection{RAINWATER HARVESTING (RWH) POTENTIAL}

On the basis of long-term average annual rainfalls, Pakistan has significant potential for RWH from various sources including irrigated areas, rainfed areas, desert areas, coastal areas, and hill torrents as shown in Figure 2. The utilization of this potential water source, with efficient techniques, can help overcome water shortage in the country, as well as help conserve natural resources and ecosystems. In rainfed areas such as Pothwar, the total rainwater potential is about 4.3 billion cubic meter (BCM), out of which only $0.1 \mathrm{BCM}$ is being harvested and utilized. The rest is leaving the area without benefiting the local communities. Similarly, there is great potential in Pakistan for rooftop RWH especially in metropolitan areas. Presently, this is one of the most underutilized approaches to water resource development in the country.

Different research organizations in Pakistan are actively involved in developing techniques and methods for RWH in various parts of the country. These organizations have made significant progress in improving designs for $\mathrm{RWH}$ in urban and desert areas, in order to provide drinking water to human populations and livestock, as well as recharge depleting aquifers.
Given the water situation in urban areas, and the need to meet future water demand, research efforts are being focused on expanding RWH techniques in urban areas. For this purpose, the current case study was conducted in the twin cities of Pakistan - Islamabad and Rawalpindi - with the main objective of exploring RWH potential in urban areas.

\subsection{RWH POTENTIAL IN TWIN CITIES}

Islamabad and Rawalpindi are twin cities with just a highway separating them. Both cities, combined with Taxila and other adjoining areas, form Islamabad/Rawalpindi (Fig. 3).

Islamabad, the federal capital of Pakistan, is spread over an area of $906 \mathrm{~km}^{2}$, out of which $220 \mathrm{~km}^{2}$ is urban area. The total population of both cities (Islamabad and Rawalpindi) in 1998 was 0.53 million and 1.4 million, respectively. This has grown to 1.01 million and 2.1 million as per recent cesus of 2017 (GoP 2017). Elevation ranges from $457 \mathrm{~m}$ to 1,604 $\mathrm{m}$. Its density is 880 people $/ \mathrm{km}^{2}$. The water table ranges from $45.72 \mathrm{~m}$ to $121.92 \mathrm{~m}$ on average but is depleting day-by-day and exploitation of groundwater is becoming comparatively expensive. The major sources of water supply of these cities are Rawal and Simly Lakes. There are several contaminant sources, including hospital waste, poultry waste, and sewerage of catchment areas, which have compromised water quality and safety (PCRWR 2016). Unhygienic water is one of the root causes of disease in the area. Simly and Rawal Lakes are therefore also not cost effective. Islamabad and Rawalpindi are among the few cities in Pakistan that receive per annum precipitation in the range of 950-1,100 $\mathrm{mm}$. The monthly trend based on the long-term record (1961-1990) is evidence of that, as shown in Figure 4.

Rainwater can successfully supplement water supplies in these cities and many other similar areas. This source of water is free from harmful environmental effects and may help in sustainable development. Present water demand is 0.775 MCM per day from Simly and Khanpur Dams. There are an additional 193 tubewells in Islamabad. The maximum water supply capacity to the city is $0.370 \mathrm{MCM}$ per day as shown in Figure 5, and can drop to $0.264 \mathrm{MCM}$ per day, resulting in a shortage to the tune of $0.467 \mathrm{MCM}$ per day.

The normal size of residential plots in Islamabad (Table 2) ranges from $74.32 \mathrm{~m}^{2}$ to $1,672.26 \mathrm{~m}^{2}$. The volume of rainwater available for a typical house of $418 \mathrm{~m}^{2}$
(90\% covered areas), with $80 \%$ collection efficiency, is given in Table 3, on a monthly and annual basis. The annual water requirement for a family of 6 people, at the rate of $0.1 \mathrm{~m}^{3}$ per head, is $248.7 \mathrm{~m}^{3}$. The total available water from a house of $418 \mathrm{~m}^{2}$ is $319 \mathrm{~m}^{3}$, this requirement therefore could easily be met from rainwater.

\section{GROUNDWATER RECHARGE BY RWH}

Generally, about $20 \%$ of rainwater percolates into the ground to recharge the aquifer. This percentage is being further reduced in $\mathrm{Pa}-$ kistan by deforestation, increased urbanization, and road and pavement construction, among other causes. In Islamabad, 4.6-6.1 m drawdown occurs every year due to unplanned extractions by the current tube wells in Islamabad and the growth in the number of tube wells in Rawalpindi, as shown in Figure 6 and Figure 7 , respectively. This in turn causes:

- short surface supplies, exerting great stress on groundwater resources;

- a continuous increase in groundwater utilization;

- a falling water table in 26 out of 43 canal commands;

- and a continuously declining water table in major cities.

There are several methods of artificial groundwater recharge, including injection wells, ditches, soakways, delay action dams, and leaky dams. It is however, necessary to evaluate the appropriate technologies of RWH in order to rejuvenate depleting fresh water aquifers. The effective implementation of appropriate artificial recharge techniques, in conjunction with RWH, would help sustainable management of groundwater, as well as the water resources of the country as a whole. Depleting aquifers may be recharged by utilizing RWH efficiently by adopting techniques of inverted well or soakways.

\subsection{AQUIFER RESTORATION WITH INVERTED WELLS}

Inverted wells are essentially pumped wells in reverse as the water enters the aquifer over a small area. Recharge/injection wells are used where the cost of land is very high, such as in urban areas, or the aquifer to be recharged is deep and/ or limited. In operation, it is essentially the opposite of groundwater abstraction, thus a recharge mound forms rather than a cone of depression when pumping. These systems are susceptible to clogging by suspended solids in the inject- 
Table 1. Water availability and demand in Pakistan (Sheikh 2017)

\begin{tabular}{|l|c|c|}
\hline Year & 2004 (BCM) & 2025 (BCM) \\
\hline Water availability (including drinking water) & 128 & 128 \\
\hline Requirement (including drinking water) & 142 & 142 \\
\hline Overall shortfall & $11 \%$ & $31 \%$ \\
\hline
\end{tabular}

Table 2. Plot sizes in Islamabad

\begin{tabular}{|l|l|l|l|l|l|l|l|l|l|}
\hline \multicolumn{10}{|c|}{ Plot sizes in $\mathrm{m}^{2}$} \\
\hline $1,672.26$ & $1,003.35$ & 836.13 & 551.84 & 501.68 & 297.29 & 227.6 & 167.23 & 116.13 & 74.32 \\
\hline
\end{tabular}

Table 3. Monthly availability of rainwater for a house on an average plot size of $418 \mathrm{~m}^{2}$

\begin{tabular}{|c|c|c|c|c|}
\hline Month & $\begin{array}{c}\text { Average rain } \\
{[\mathrm{mm}]}\end{array}$ & $\begin{array}{c}\text { \% of annual } \\
\text { rainfall }\end{array}$ & $\begin{array}{c}\text { Rooftop rainwa- } \\
\text { ter }\left[\mathrm{m}^{3}\right]\end{array}$ & $\begin{array}{c}\text { Total rainwater for a } \\
\text { house of } 418 \mathrm{~m}^{2}\left[\mathrm{~m}^{3}\right]\end{array}$ \\
\hline Jan & 56.1 & 4.91 & 8.70 & 15.7 \\
\hline Feb & 73.5 & 6.44 & 11.86 & 21.3 \\
\hline Mar & 89.8 & 7.86 & 13.93 & 25.1 \\
\hline Apr & 61.8 & 5.41 & 9.58 & 17.2 \\
\hline May & 39.2 & 3.43 & 6.10 & 10.9 \\
\hline Jun & 62.2 & 5.45 & 9.60 & 17.3 \\
\hline Jul & 267 & 23.38 & 41.2 & 74.1 \\
\hline Aug & 310 & 27.15 & 48.00 & 86.5 \\
\hline Sep & 98.2 & 8.60 & 15.22 & 27.5 \\
\hline Oct & 29.3 & 2.57 & 4.54 & 8.2 \\
\hline Nov & 17.8 & 1.56 & 2.70 & 4.9 \\
\hline Dec & 37.3 & 3.27 & 5.75 & 10.4 \\
\hline Total & $1,142.2$ & 100.00 & 177.21 & 319.0 \\
\hline
\end{tabular}

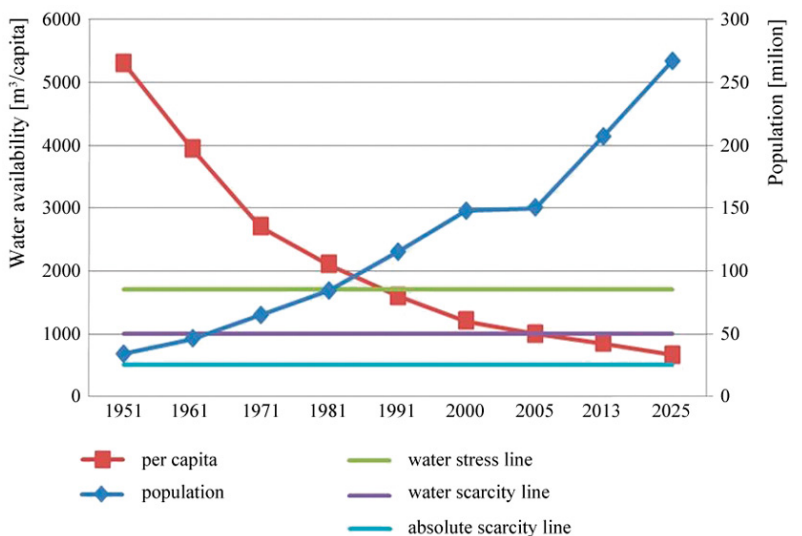

Fig. 1. Population growth vs. non-agricultural water demand (PWP 2000)

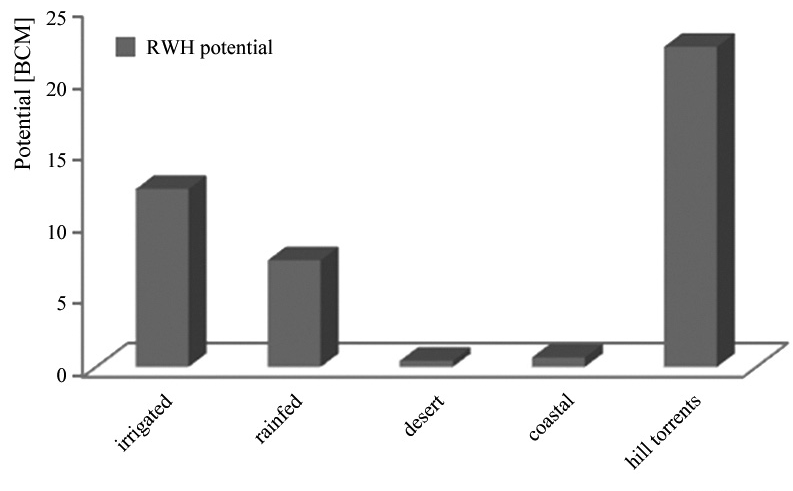

Source areas

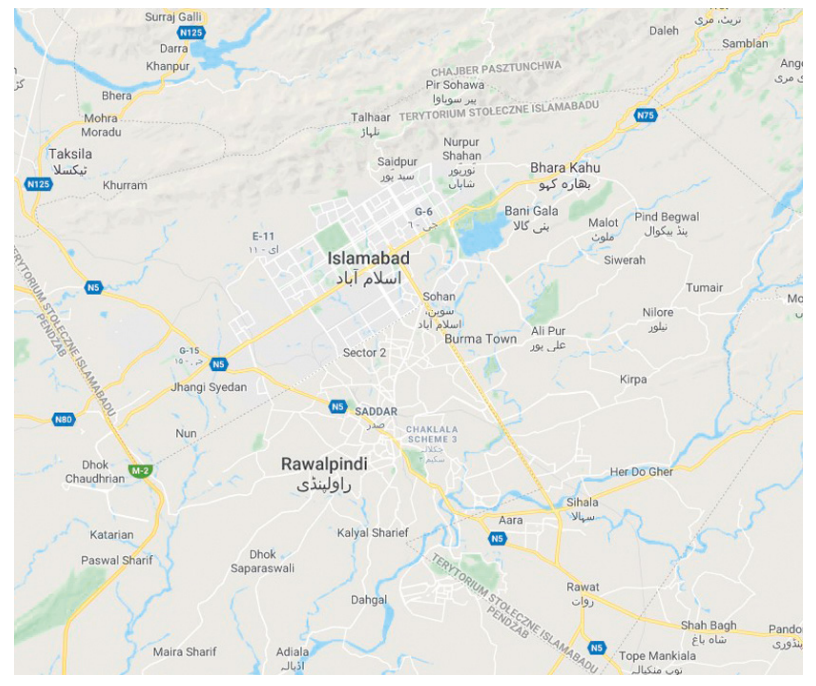

Fig. 3. Combined map of Islamabad and Rawalpindi cities

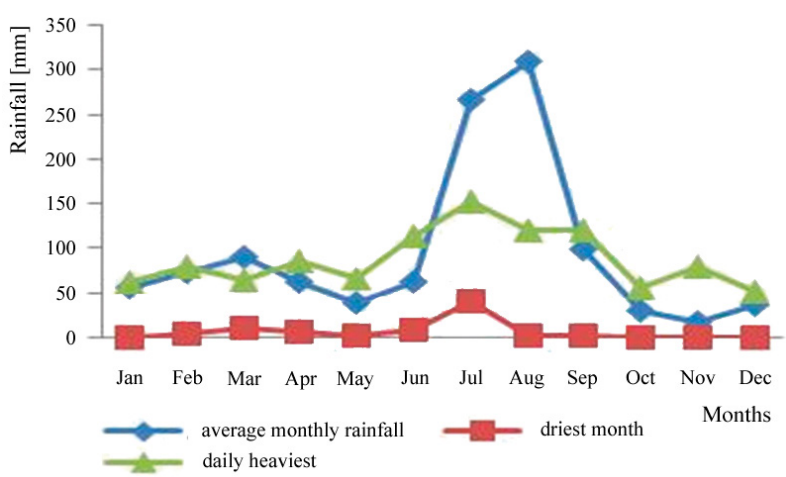

Fig. 4. Monthly average rainfall pattern for Islamabad and Rawalpindi (source: Pakistan Meteorological Department; heaviest rainfall of 23 July 2001 not included)

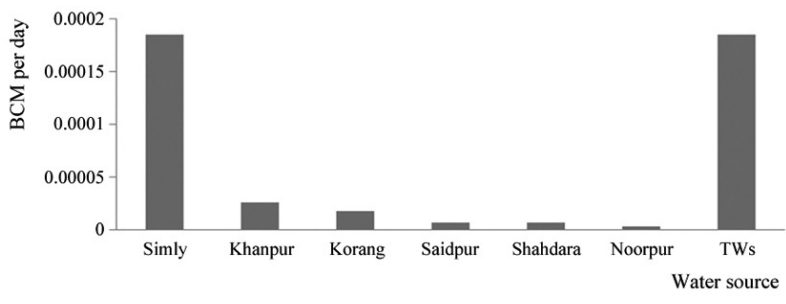

Fig. 5. Daily water supply from various sources to Islamabad (source: Capital Development Authority)

Fig. 2. Pakistan-RWH potential (source: Proceedings of Regional Groundwater Management Seminar, October 9-11.2000 Islamabad) 


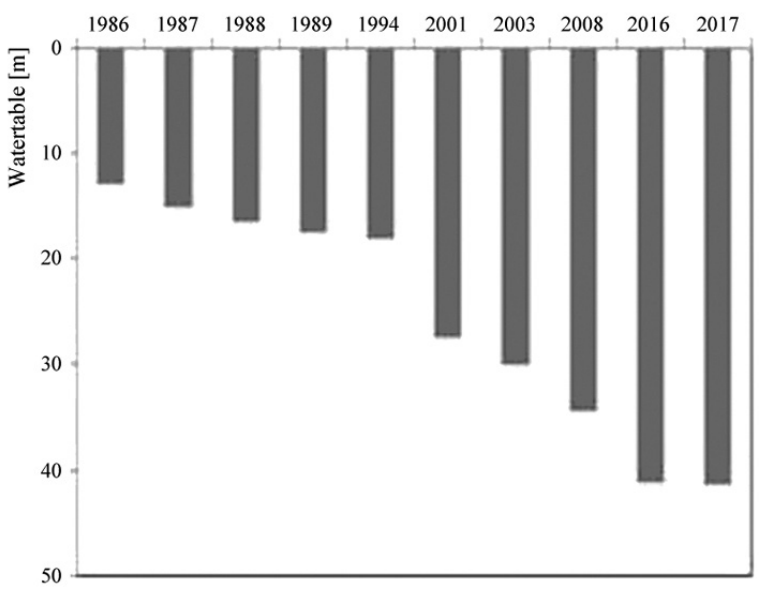

Fig. 6. Yearly trend of ground water depletion in Islamabad (source: PCRWR 2016, 2018)

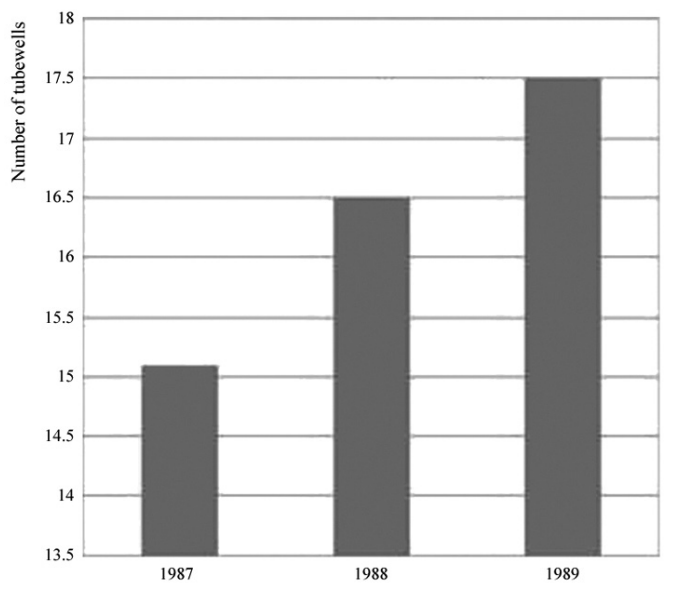

Fig. 7. Yearly trend of tube well increase in Rawalpindi (source: Water and Sanitation Agency, Rawalpindi)
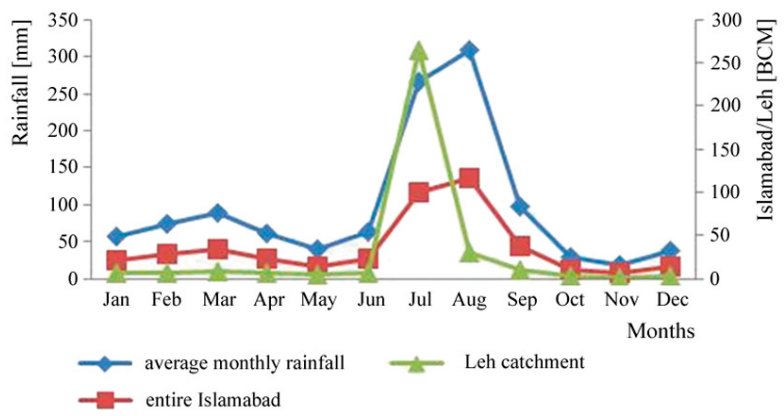

Fig. 8. Surface run-off of Islamabad and Leh catchment area

ed water. Afforestation and vegetative measures in the catchment are necessary to control sedimentation.

\subsection{AQUIFER REVIVAL WITH SOAKWAYS}

Soakways are another method of artificial groundwater recharge. This method consists of permeable materials located below ground to store runoff, which is utilized for flow to ground water. The permeable surface can be grassed or graveled areas, paving blocks with vertical voids built in, or paving blocks with gaps between individual units. Water is therefore collected from a large surface area, stored in the filter drains, and allowed to infiltrate through the soil. Soakways trap sediments and thereby clean the run-off. It is essential that the surface is kept clear of silt and cleaned regularly to keep the voids clear.

In order to develop the above-defined (3.1 \& 3.2) techniques, the catchments of different sites in Islamabad would need to be surveyed for these purposes. Then necessary diversions, if required, would need to be developed to direct rainwater towards the points in the catchment where inverted wells or soakways would be implemented.

\subsection{GREEN BELTS FOR GROUNDWATER RECHARGING}

Green belts, which are 91.44 meter by 182.88 meter wide, and are positioned astride roads, can be used for easy groundwater recharge as well. Natural depressions in these green belts can store rainwater. By considering an average storage of $100 \mathrm{~m} \times 100 \mathrm{~m} \times 10 \mathrm{~m}$ $(100,000 \mathrm{cum})$ per $\mathrm{km}$ for $280 \mathrm{~km}$ long greenbelts, it would be possible to store $280 \times 100,000$ or $28 \mathrm{MCM}$. As an example, the green belt south of Shaker Parian and sports complex, which is equal to one sector of $2 \mathrm{~km}$ by $2 \mathrm{~km}$, would be capable of storing $2000 \times 2000 \times 10$, or $40 \mathrm{MCM}(\mathrm{Li}$ aqat 2002).

\section{RWH FOR FLOOD PREVENTION \\ IN RAWALPINDI}

The catchment area of Nullah Leh is $238 \mathrm{~km}^{2}$, while the Islamabad Territory area is $908 \mathrm{~km}^{2}$, from which surface runoff is generated during the rainy season. The monthly and total runoff generated in the entire Islamabad and Leh catchment, assuming $50 \%$ efficiency, is shown in the Figure 8.

Figure 8 shows about 130.24 MCM of runoff per year is generated by Nullah Leh; this quantity is enough to supply water to Islamabad for one year at the rate of 0.37 million $\mathrm{m}^{3}$ per day. Capturing and storing rainwater for use is particularly important in dry lands, hilly, urban, and coastal areas. Humans can survive hunger for several weeks if the body possesses sufficient reserves. Lack of water, however, will lead to certain death within days, as the body cannot retain any water reserves. Therefore, we must take stock of the situation and adopt innovative methods and techniques to store and conserve water.

Many countries of the world have realized the importance of RWH and are successfully benefiting from it. Before the situation becomes worse and the minimum water required for essential needs is not available, we must evolve innovative methods of saving water and supplementing our existing water resources by harvesting rainwater. The following recommendations are made with special reference to Rawalpindi and Islamabad. 


\section{RECOMMENDATIONS/ CONCLUSIONS}

a. The annual runoff in the Potohar region is $4.32 \mathrm{BCM}$, but only a fraction of this is being harvested. Numerous dam sites have been identified in the Islamabad and Rawalpindi area, but in the past several decades, no rainwater storage dams have been constructed in the twin cities. The existing dam sites should be prioritized and new dam sites should also be identified. Construction of new dams should be given top priority in the Annual Development Program and construction of at least one dam per year should be mandatory by each of these two cities.

b. Rooftop RWH must be made obligatory for all citizens of Islamabad and those people of Rawalpindi who live on a plot of $418 \mathrm{~m}^{2}$ or more. All government buildings must install RWH systems. Construction of RWH systems should be made part of the building bylaws.

c. Subsidies may be given to tenants who adopts RWH techniques via property taxes. In Japan subsidy is given to people to install RWH systems. In Australia special loans are provided by banks for RWH.

d. Penalties may be imposed on residents who dispose of rainwater into storm drainage. In Bon, Germany, households pay a special tax depending upon the amount of storm water they allow into a storm water drain.

e. There is currently no control on the extraction of groundwater and there are no bylaws which restrict or control the pumping out of ground water. It should be compulsory for every agency that extracts groundwater to construct recharging wells in order to recharge the aquifer by harvesting rainwater. The recharging systems should be designed so that the amount of recharge is at least equal to the amount of ground water extracted during the year. Necessary byelaws are needed to restrict extraction of ground water. Concerned agencies should have a record of each tube well in their area and the residential units that have installed water pumps/electric motors to extract ground water.

f. As part of building bylaws, residents should have separate water disposal systems for sewage water and other grey water (e.g., wash basin, kitchen). Sewage water may be drained to a treatment plant for agricultural and irrigation purposes, whereas other water can be used for lower quality water uses. g. Water charging ponds in open spaces, dams and check dams in nullahs, and distributaries, should be constructed. These ponds will store water for emergency and recharging of ground water. Fatima Jinnah Park and the green belts astride main roads in Islamabad are ideal places to harvest rainwater by making water ponds or recharging wells.

$h$. The water saving techniques given in this paper are being successfully applied in other countries. We need to encourage our people to use them. All government buildings should have these techniques incorporated into their design and construction.

i. It is a very common sight to see people using high quality municipal water for uses such as watering of lawns or washing cars. Although there are laws to punish the culprits, the fine is so minor that it does not deter people. Municipal laws must be amended and these fines should be increased by a substantial amount.

j. A mass campaign on TV, radio, and print media should be launched to create awareness of RWH, recycling of water, and water saving techniques.

\section{NOTATIONS}

RWH - Rainwater harvesting; UNEP - United Nation Environment Program; MCM - Million Cubic Meter; BCM - Billion Cubic Meter; CDA - Capital Development Authority; $\mathrm{m}^{2}$ - square meter; TV - Television; TW Tubewell; GoP - Government of Pakistan.

\section{REFERENCES}

- Ariyabandu R.S., 1999, Water security through rainwater harvesting, [in:] $25^{\text {th }}$ WEDC Conference on integrated development for water supply and sanitation, Addis Abba, Ethiopia,166-168

- Aladenola O.O., Adeboye O.B., 2010, Assessing the potential for rainwater harvesting, Water Resources Management, 24 (10), 2129-2137, DOI: 10.1007/s11269-009-9542-y

- Chubaka C.E., Whiley H., Edwards J.W., Ross K.E., 2018, A review of roof harvested rainwater in Australia, Journal of Environmental and Public Health, DOI: 10.1155/2018/6471324

- GoP, 2017, Census of Pakistan, Government of Pakistan, Pakistan Bureau of Statistics, http:// www.pbs.gov.pk/content/population-census

- Handia L., Tembo J.M., Mwiindwa C., 2003, Potential of rainwater harvesting in urban Zambia, Physics and Chemistry of the Earth, Parts A/B/C, 28 (20-27), 893-896, DOI: 10.1016/j. pce.2003.08.016

- Kahlown M.A., Ashraf M., 2002, Water management strategies under drought conditions, [in:] Proceedings of the SAARC workshop on drought and water management strategies, 16-18 September 2002, Lahore, Pakistan, 47-57

- Kahlown M.A., Majeed A., 2002, Water status and management is Pakistan, [in:] Water and new technologies, I. Ahmed (ed.), Global Change Impact Studies Centre, Islamabad

- Kharal L., 2002, Artificial recharge of groundwater by injection well, [in:] $28^{\text {th }}$ WEDC Conference: Sustainable Environmental Sanitation and Water Services, Calcutta, India, available at file:///C:/Users/rstepnowski/Desktop Kharal.pdf (data access 08.11.2019)

- Liaqat A., 2002, Rainwater harvesting in urban areas, The Corps of Engineers Journal, Military College of Engineering, Risalpur, Pakistan

- PWP, 2000, Framework for Action for Achieving the Pakistan Water Vision 2025, Pakistan Water Partnership, 75 pp.

- PCRWR, 2016, Water quality status of major cities of Pakistan 2015-16, Pakistan Council of Research in Water Resources, Islamabad, available at http://www.pcrwr.gov.pk/publication.php?view_quality (data access 08.11.2019)

- PCRWR, 2018, Water situation in Islamabad, Pakistan Council of Research in Water Resources, Islamabad, available at www.pcrwr. gov.pk (data access 08.11.2019)

- Rahman A., Dbais J., Imteaz M.A., 2010, Sustainability of rainwater harvesting systems in multistorey residential buildings, American Journal of Engineering and Applied Sciences, 3 (1), 73-82, DOI: 10.3844/ajeassp.2010.73.82

- Sazakli E., Alexopoulos A., Leotsinidis M., 2007, Rainwater harvesting, quality assessment and utilization in Kefalonia Island, Greece, Water Research, 41 (9), 2039-2047, DOI: 10.1016/j.watres.2007.01.037

- Sheikh A.A., 2017, Technological gaps and innovation endeavours relating safe and sustainable water in developing countries, Asia-Pacific Tech Monitor, 34 (3), 14-22

- Steffen J., Jensen M., Pomeroy C.A., Burian S.J., 2013, Water supply and stormwater management benefits of residential rainwater harvesting in US cities, Journal of the American Water Resources Association, 49 (4), 810-824, DOI: 10.1111/jawr.12038

- Teston A., Geraldi M.S., Colasio B.M., Ghisi E., 2018, Rainwater harvesting in buildings in Brazil: a literature review, Water, 10 (4), DOI: 10.3390/w10040471

- Ward S., Memon F.A., Butler D., 2012, Performance of a large building rainwater harvesting system, Water Research, 46 (16), 5127-5134, DOI: 10.1016/j.watres.2012.06.043 